\title{
Petrographic and Geochemical Study of Low Grade Metamorphic Rocks around Negash with Reference to Base Metal Mineralization and Groundwater Quality, Tigray, Northern Ethiopia
}

*K. Bheemalingeswara and Nata Tadesse

Department of Earth Science, College of Natural and Computational Sciences, Mekelle University, P.O. Box 3066, Mekelle, Ethiopia (*kbheema@hotmail.com)

\begin{abstract}
Petrographic and geochemical data of Upper Proterozoic, low grade metamorphic rocks (Tsaliet Group) in and around Negash is interpreted in this paper with their mineralization potential and influence on groundwater quality. Among the three types of metamorphic rocks, metavolcanics (MV), metavolcaniclastics (MVC) and metasediments (metapelites) (MP) are present in the study area. Metavolcanics are massive, non-foliated and show presence of relicts of plagioclase feldspar and pyroxenes set in a fine grained matrix. Metavolcaniclastics show presence of clasts set in a fine grained tuffaceous groundmass and indicate a significant compositional contrast between these, probably volcanic derived, groundmass and the clasts. The clasts vary in size and shape from angular, subrounded to rounded and even elliptical (due to shearing). Phyllite, the predominant lithounit of metasediments is composed of fine grained muscovite, quartz and chlorite with incipient foliation and at places well developed crenulations. Presence of chlorite together with poorly developed muscovite and biotite (rare) suggests low grade metamorphic conditions that prevailed in the area. Geochemical data of metavolcanics indicate variation in their composition from basalt to andesite. Metavolcaniclastics are relatively enriched in alkalis and silica and deficient in MgO compared to metavolcanics. Phyllite on the other hand is enriched in $\mathrm{K}_{2} \mathrm{O}$ and silica compared to metavolcanics. Development of chlorite, sericite and other minerals due to low grade metamorphism and hydrothermal alteration have modified the chemistry of the rocks particularly MgO by chlorite in phyllite.

Shear zones are common in the rocks of the study area, trending N-S and showing presence of clasts with non-ideal tails, relatively higher amount of quartz veins, malachite stains, $\mathrm{Cu}$ anomalies and sericitisation. These stains and anomalies strongly suggest a shear zone-controlled copper mineralization. Island arc-setting, bimodal volcanism, intrusive granitic plutons and similar type of shear zone -controlled Zn-mineralization in the nearby Abrha Atsbha area indicate possible presence of a similar kind of mineralization elsewhere in the basement rocks around these plutons.

Hydrogeochemical data indicate that groundwater is relatively fresh and among major elements $\mathrm{Na}$, Ca and $\mathrm{Mg}$ show relatively higher values compared to $\mathrm{K}$. Water from metasediments is relatively harder among others. Na though shows higher values compared to Ca and Mg does not indicate any particular trend. $\mathrm{Ca}$ and $\mathrm{Mg}$ concentrations are related to the mafic and plagioclase feldspar minerals. Among trace elements, iron, nickel and lead show relatively higher values compared to other analyzed elements. $\mathrm{Fe}$ and $\mathrm{Ni}$ are related to metavolcanics and metavolcaniclast, and $\mathrm{Pb}$ to metapelite.
\end{abstract}

Key words: Low grade metamorphic rocks, Base metal mineralization, Petrography, Hydrogeochemistry, Negash, Ethiopia 


\section{INTRODUCTION}

The need for natural resources in the development of a country is an undisputable issue. The resources are available either on the surface or subsurface of the Earth. Search for these resources whether mineral or water thus mainly targets the Earth's crust. The resources are the result of a particular or combination of geological processes and occur in a suitable geological condition. A variety of exploration methods such as geological, geochemical and geophysical either single or in combination are employed in search of these resources, keeping in view the geology of the area and type of resource. The basement or Precambrian terrains which are invariably metamorphosed, tectonically disturbed and affected by intrusive plutons are some of the potential targets for a variety of mineral deposits e.g. base metal sulphides, native gold, skarn, greisen, pegmatite etc). Use of mineral deposit genetic models has become an important step in outlining prospective areas regionally in the search of mineral resources. A preliminary investigation related to geological mapping, petrography, alterations, and geochemistry provides the information whether to undertake a detailed survey or not. It is very common that in majority of the cases the ore deposits that we come across may be of low grade and uneconomical. Though the deposits are commercially uneconomical, they contributed in high quantities of metals to the percolating meteoric water and circulating groundwater. The constant interaction of water with ores and gangue minerals facilitate leaching and release of metals into the aquifer system, depending on the nature of solubility of different minerals and geochemical condition. $\mathrm{pH}$ is one of the factors (other than Eh) that has strong influence on the behaviour of trace metals in the surface environment. For example, decrease of $\mathrm{pH}$ by one unit may lead to an increase of more than one order of magnitude in the concentration of certain metals like $\mathrm{Al}$, Be (Edmunds and Smedley, 1996). Increase in the acidity of groundwater is a common feature particularly in non-carbonate areas (e.g. granite) or in areas where oxidation of sulphides (e.g. pyrite) is common. Such changes are also common when there is a change from oxidizing to reducing conditions (e.g. Fe). Some metals like $\mathrm{Cu}, \mathrm{Zn}$ and As become mobile in oxidizing conditions and others like Fe and Mn under reducing conditions. Hardness of water is one of the parameters which depend on the concentration levels of $\mathrm{Ca}$ and $\mathrm{Mg}$. It is known that many metals are soluble in soft water resulting in the enrichment of metals in water (Edmunds and Smedley, 1996). Any one or combination of these may cause mobility and concentration of metals. Such changes often enhance the concentration of many elements particularly trace metals 
to intolerable proportions and become a serious threat to human health. The quality requirement of groundwater depends on its purpose of use i.e. for drinking, industry, irrigation etc. So, the suitability is generally tested on the basis of hardness, sodium absorption ratio, total dissolved solids, conductivity etc. So, the mineral deposit whether of high or low grade affects the groundwater quality. The effects on health will be more intense in the case of metallic compared to the non-metallic deposits.

In this light, an area around Negash in Tigray region of northern Ethiopia, a Neoproterozoic metamorphic terrain was chosen for study with the purpose of evaluating the metamorphic rocks, their potential to host mineral deposits and influence on groundwater quality. To achieve this objective, the metamorphic rocks were probed for petrographic and geochemical characteristics and the information on (a) primary mineralogy; (b) textural relations; (c) alterations or changes in the primary mineralogy due to hydrothermal or meteoric water activity; (d) metal concentrations associated with shear zones and possible relation to mineralization; (e) presence of secondary minerals like limonite or malachite; and (f) trace metal geochemistry of groundwater to define its quality and utility value is obtained.

The area of study around Negash is located about $45 \mathrm{~km}$ from Mekelle towards north on the way to Adigrat and forms part of Tigray region, northern Ethiopia. It is located between $13^{0} 50^{\prime} 20^{\prime \prime}$ to $13^{0} 58^{\prime} 34^{\prime \prime} \mathrm{E}$ and $39^{0} 33^{\prime} 20^{\prime \prime}$ to $39^{0} 38^{\prime} 15^{\prime \prime} \mathrm{N}$ (Fig.1) and covers an area of about $144 \mathrm{Km}^{2}$. It is connected by an asphalt road which makes it accessible in all weather conditions. Interconnecting cross roads though are of gravel, are also accessible for vehicles even during rainy season.

\section{REGIONAL GEOLOGY}

The Precambrian basement rocks of northern Ethiopia are predominantly composed of metavolcano-sedimentary assemblage (Kazmin, 1973; Tadesse, 1996; Drury and De Souza, 1998). They form part of the southern part of the Arabian-Nubian Shield (ANS) (Kazmin et al., 1978; Vail, 1983, 1988), which in turn constitute a large segment of juvenile Neoproterozoic crust formed by accretion of oceanic arc terrains (Stoeser and Camp 1985; Stern 1994; Genna et al., 2002; Johnson and Woldehaimanot 2003). The ANS is flanked by the older basement, which was remobilized during the Pan-African orogenic cycles (850-550 Ma) and eventually led to the formation of Gondwana. The Precambrian basement rocks of Ethiopia including northern 


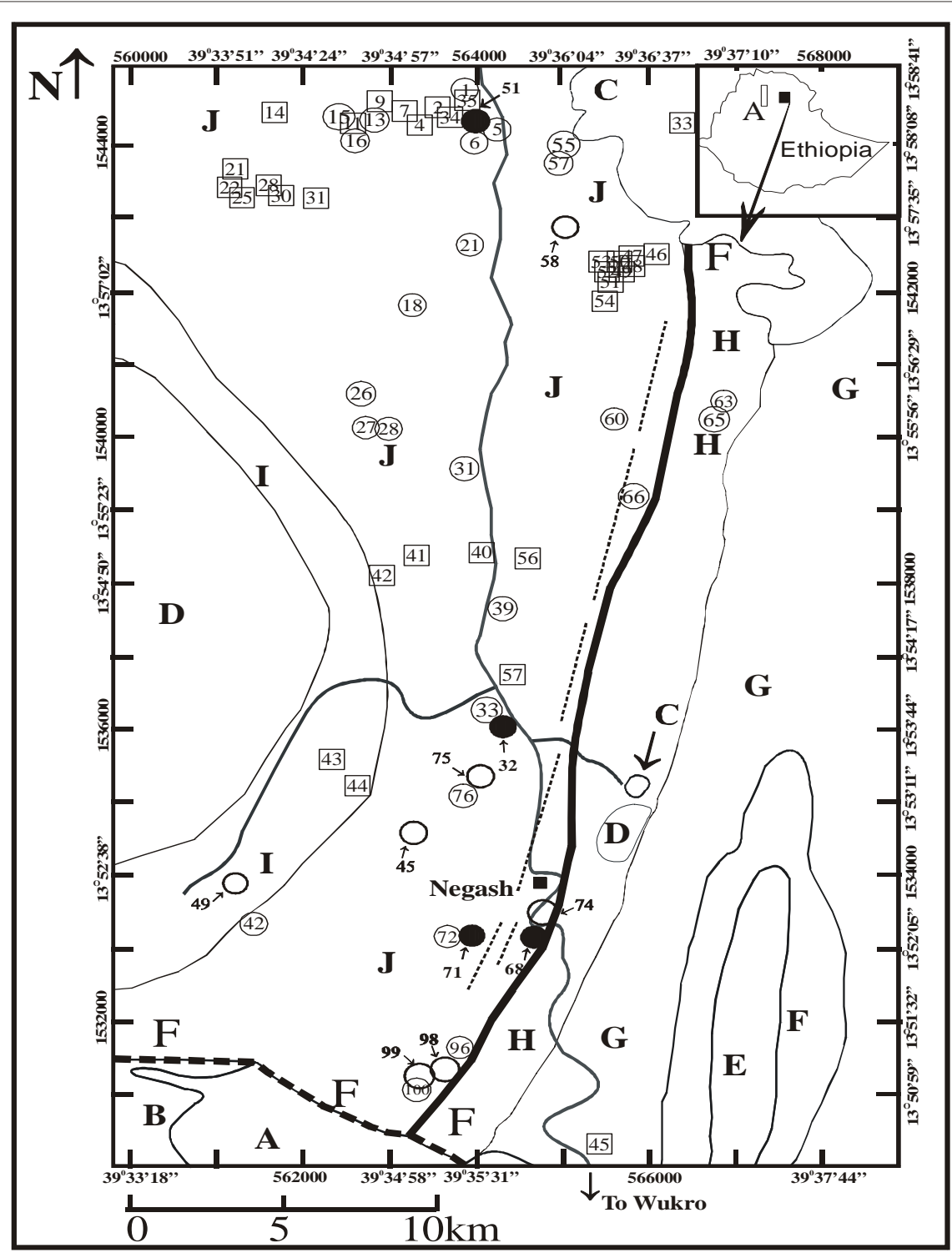

LEGEND

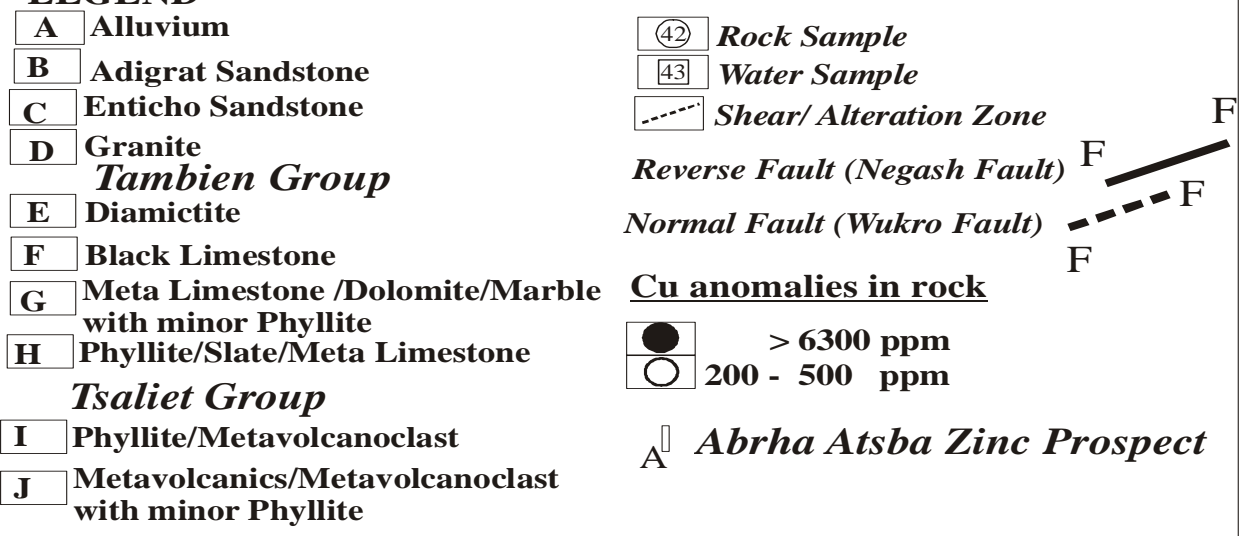

Figure.1. Geological, rock, water sample location map around Negash, Tigray, Northern Ethiopia (modified after Arkin et al., 1971). 
Ethiopia have been studied by many workers. They include, Kazmin et al. (1978) on stratigraphy and evolution; Shackleton (1994, 1996), Stern (1994), Abdeselam and Stern (1996), Tadesse (1996), Tadesse and Allen (2002), Genna et al. (2002), and Johnson and Woldehaimanot (2003) on sutures and shear zones; Ayalew et al. (1990), Gichile (1992), Teklay et al. (1998) and Gerra (2000) on geochronology. Studies are also conducted on the metamorphic rocks of northern Ethiopia by Tadesse et al. (1999) and Alene et al. (2000) on geochemistry and tectonic setting.

Kazmin et al. (1978) have divided the Precambrian basement of Ethiopia in to Upper, Middle and Lower Complexes on the basis of the grade of metamorphism. The low grade rocks belonging to Upper Complex and high grade to Lower Complex and medium to Middle Complex. They also considered the Upper Complex rocks to be Late Proterozoic in age and Middle and Lower Complexes to be Middle and Early Proterozoic (or Late Archean). But recent studies on the basis of the geochronological and isotopic data (Gerra, 2000, Teklay et al., 1998 and others) have suggested that the Precambrian basement rocks are dominantly Neoproterozoic in age and have experienced different grades of metamorphism. In tune with the geochronological and other data, the basement rocks are regrouped into two major blocks, Volcanic-sedimentary terrain (including the younger metasediments) and the Gneisic migmatitic terrain, separated by numerous Ophiolitic sutures (Asrat et al., 2001).

\section{GEOLOGY OF THE STUDY AREA}

The rocks of the study area form part of the basement and belong to Upper Complex of Kazmin et al. (1978) and have experienced low grade metamorphism during Neoproterozoic (Gerra, 2000, Ayalew et al., 1998, Teklay et al., 1998). The rocks mainly trending N-S to NE-NW though present in northern, western and southern parts of the country, are predominant in the north. The rocks indicate greenschist facies metamorphism and represent a volcano-sedimentary succession (Kazmin et al., 1978). They are invaded by felsic plutons such as granodiorite/ granite rocks in the west (Negash pluton) and pink granite in the eastern part of the study area (Fig.1). The emplacement of Negash pluton marks the end of Proterozoic, on the basis of U-Pb dating of zircons, around $608 \pm 7$ Ma (Asrat, 2002). This emplacement represents the last of the three granitic magmatism episodes: 800-885 Ma, 700-780 Ma and 540-660 Ma that have taken place 
in Ethiopia (Garland, 1980; Miller et al., 1967; Mock et al., 1999; Alemu, 1998; Tadesse, et al., 2000; Ayalew et al., 1990; Rogers et al., 1965; Jelene, 1996; Gilboy, 1970; Teklay et al., 1998). These ages are also considered to be related to the major structural and metamorphic events in different terrains in Ethiopia (Teklay et al., 1998; Ayalew et al., 1990; Tadesse, et al., 2000). The basement rocks in the study area are classified under Tsaliet and Tambien Groups (Kazmin et al., 1978). Tsaliet Group rocks are older and dominated by metavolcanics, metavolcaniclastics and metasediments/ metapelites. MV is the oldest and MP is the youngest. The younger Tambien Group consists of only metasediments. They are, in the order of older to younger, phyllitemarble-dolomite intercalation, meta-limestone (black limestone), slate and diamictite (pebbly slate) and form part of Negash syncline (Miller et al., 2003) (Fig.1).

The area is also marked by the presence of two prominent faults, Negash fault trending N-NE and the younger Wukro fault trending E-W (Fig.1). Negash fault is a thrust fault where the younger Tambien Group rocks have thrusted over the older Tsaliet Group rocks (Fig.1). Since the fault is involved between the Tambien and Tsaliet Group rocks and also confined to the basement rocks, it may be related to the age of the Negash pluton. Wukro fault is a normal fault and much younger in age and involved in the upliftment of the basement rocks (Negash) with relation to the Mesozoic sedimentary rocks (Wukro) of the Mekelle basin. The intrusive granitic plutons and related tectonic activity has facilitated generation and mobility of ore- forming hydrothermal fluids within the basement rocks. Further, the fluid-wall rock interaction has produced alterations e.g. epidotisation, sericitisation by modifying the primary mineral assemblages.

Among the rocks of Tsaliet and Tambien Groups, only the rocks of Tsaliet Group are considered for the present study and discussed in the paper. Brief description of the rocks is given below.

\subsection{Metavolcanics}

These rocks are dominated by metabasalts with subordinate meta-andesites and metarhyolites. The metabasalts are massive, non-foliated, fine-grained and typically show green color. Metaandesites are also massive, non-foliated and show dark grey color. Metarhyolites with limited occurrence show light pink color. Development of alterations such as epidotisation and chloritisation are common in this unit. MV is dominant in the central part of the study area. Kaolinisation is also common in the metarhyolites. Metabasalt being the dominant rock type in the area is considered for detailed petrography and geochemistry. 


\subsection{Metavolcaniclastics}

These rocks are relatively predominant in the area and occupy a large part of the study area. MVC shows significant variation in the size, shape and chemical composition of the clasts and in turn overall rock composition. The clasts vary in size from very coarse in the east to fine in the west. They also vary in shape from angular, elongated (elliptical), sub-rounded to round. The clasts are mainly lithic and mineral fragments varying in composition from mafic (amphiboles/ pyroxenes) to felsic (feldspars and quartz). The matrix consists of fine grained material at places shows green color. The clasts in general show random orientation and at places show alignment indicating fluvial transport. On the basis of the field association, lack of proper sedimentary characteristics, fine grained matrix and clasts with varying composition and random orientation, the rock is considered to be volcanic-derived with limited amount of sedimentary input. Pyrite crystals are common in the rock but mostly are altered to limonite.

\subsection{Metasediments}

These are represented by phyllite and slate. Megascopically the rocks are fine-grained and show well developed foliation in phyllite and slaty cleavage in slate. These rocks are more prominent in the eastern and western parts of the study area and show a range of colors such as light grey, dark grey, green and brown/red. Development of crenulation cleavage is prominent at places. Schistosity, though is poorly developed, is seen along the contacts with the intrusive pluton where development of muscovite is quite prominent. Presence of pyrite crystals with cubic outline is quite conspicuous in these rocks. In majority cases these are altered to limonite (pseudomorphs) and show red color.

\subsection{Shear Zones}

The zones trending N-NE are characterized by the presence of tails of non-ideal simple stress. The rigid clasts (lithic fragments) show rotation and developed cracks during the shearing of the matrix. The tails or the pressure shadows extend on either side of the clasts and the rotation of the clasts is marked by the layers/ tails being rolled around the rigid clasts (David, 1993). In the field, these zones are common in MVC and MP. The rigid clasts also show breakdown producing cracks possibly due to stretching and rotation. They are later filled by the fine grained matrix. Relatively well developed foliation/schistosity/crenulations, increased quartz vein activity, sericitisation and malachite stains are some of the common features associated with these zones. Presence of green colored malachite is quite conspicuous in these zones indicating base metal 
mineralization. These zones vary in width from less than a meter to few meters and most common along the contacts between MV, MVC and MP. It is interesting to note that these zones are prominent only in Tsaliet Group rocks not in Tambien Group. Precambrian stratigraphic succession of the rocks in the study area, from younger to older, is as given below (Kazmin et al., 1978; Miller et al., 2003).

\title{
Tambien Group
}

Granit and, Granodiorite (Negash pluton) (Intrusive Plutons)-----

\author{
[Undifferentiated units (Negash Syncline) ( 1750m thick)] \\ Diamictite (pebbly slate) \\ Black limestone \\ Metalimestone- dolomite-marble- minor phyllite \\ Phyllite- slate- metalimestone
}

\section{Tsaliet Group}

\author{
[Metapelites and Metavolcanics ( 1500m thick)] \\ Slate / Phyllite \\ Metavolcaniclastics \\ Metavolcanics
}

\section{METHODOLOGY}

A detailed geological map has been prepared in the scale of 1:50,000. 100 rock samples covering the three lithounits (MV, MVC and MP) and 27 water samples were collected during the field work around Wukro and Negash for geochemical analysis. The sample locations are given in figure 1. Out of 100 rock samples, 39 samples were selected for geochemical analysis. The rock samples were crushed and ground to obtain fine rock powders. Whole rock geochemical analysis was performed on the powdered samples. Major, minor and trace elements data was generated using X-ray Fluorescence Spectrophotometer (XRF) (Phillips PW 2024) in the Geochemical Laboratories of the Department of Applied Geology at Technical University, Berlin, Germany. Major oxides were analysed using fused beads following fusion with LiBO3 and trace elements by pressed powder pellets using boric acid as binder. The spectrometer was calibrated with a set of 30-35 International reference materials (rock standards), covering a wide range of composition and detection limits.

30 rock samples were chosen for petrographic studies. Rock thin sections were prepared for petrographic investigations at Geology Department, Delhi University, India and studied using petrological Leica Orthoplan Microscope attached with Image Analyser. 28 groundwater samples about one liter each were collected in pre-cleaned and numbered plastic bottles. The 
samples were analyzed for $\mathrm{pH}$ and EC in the site. They were acidified and later submitted for geochemical analysis using Flame Atomic Absorption Spectrophotometer (Varian Spectra, 50B) in the Geochemistry Laboratory, Department of Earth Science, Mekelle University. Elements such as $\mathrm{Ca}, \mathrm{Mg}, \mathrm{Na}, \mathrm{K}, \mathrm{Cu}, \mathrm{Pb}, \mathrm{Zn}, \mathrm{Mn}, \mathrm{Fe}, \mathrm{Ni}$ and $\mathrm{Co}$ were analyzed after setting the instrument using the prescribed standard conditions. Chemical standards in the range of 1 to $10 \mathrm{ppm}$ for each element were used for constructing standard working curve and also as reference. The detection limit for all the elements except $\mathrm{Pb}$ was $0.1 \mathrm{ppm}$. For lead, it is $1.0 \mathrm{ppm}$. The precision range for these elements was within $\pm 5-10 \%$. The petrographic data is given in table. 1 and whole rock and water sample data are given in tables 2 to 4 . All rock and water sample locations are shown in figure.1.

\section{RESULTS}

\subsection{Petrography}

Among 30 samples studied for petrographic details, 15 are from MVC, 10 from MV and 5 from MP. Petrographic details for different rock types are given in table. 1 and described below.

They are 1) metavolcanic - consists of plagioclase feldspar, hornblende, inequigranular quartz, relict and reaction textures with poorly developed schistosity indicated by chlorite. Green colored hornblende and colorless needle shaped tremolite showing random distribution and sometimes wrapping the relict pyroxenes indicate decussate texture; 2) metavolcaniclasticquartz, chlorite, muscovite, biotite, lithic fragments with different compositions, with well developed schistosity (at places), the fragments are being wrapped by the sheet silicates. The matrix comprises of fine grained material possibly volcanic derived tuff (glass). The fragments sometimes show orientation indicating flow structure and also elongation due to stretching. The fragments are irregularly distributed and vary in composition from mafic (pyroxenes) to felsic (feldspars); Mineral associations and field relations suggest that the rock is metavolcaniclastic rock. 3) phyllite- consists of fine grained quartz, chlorite and muscovite with well developed foliation and crenulations; and 4) slate- consists of similar mineralogy as in phyllite but with very fine and poorly developed foliation. 
Table 1. Petrographic description of selected metamorphic rocks, Negash.

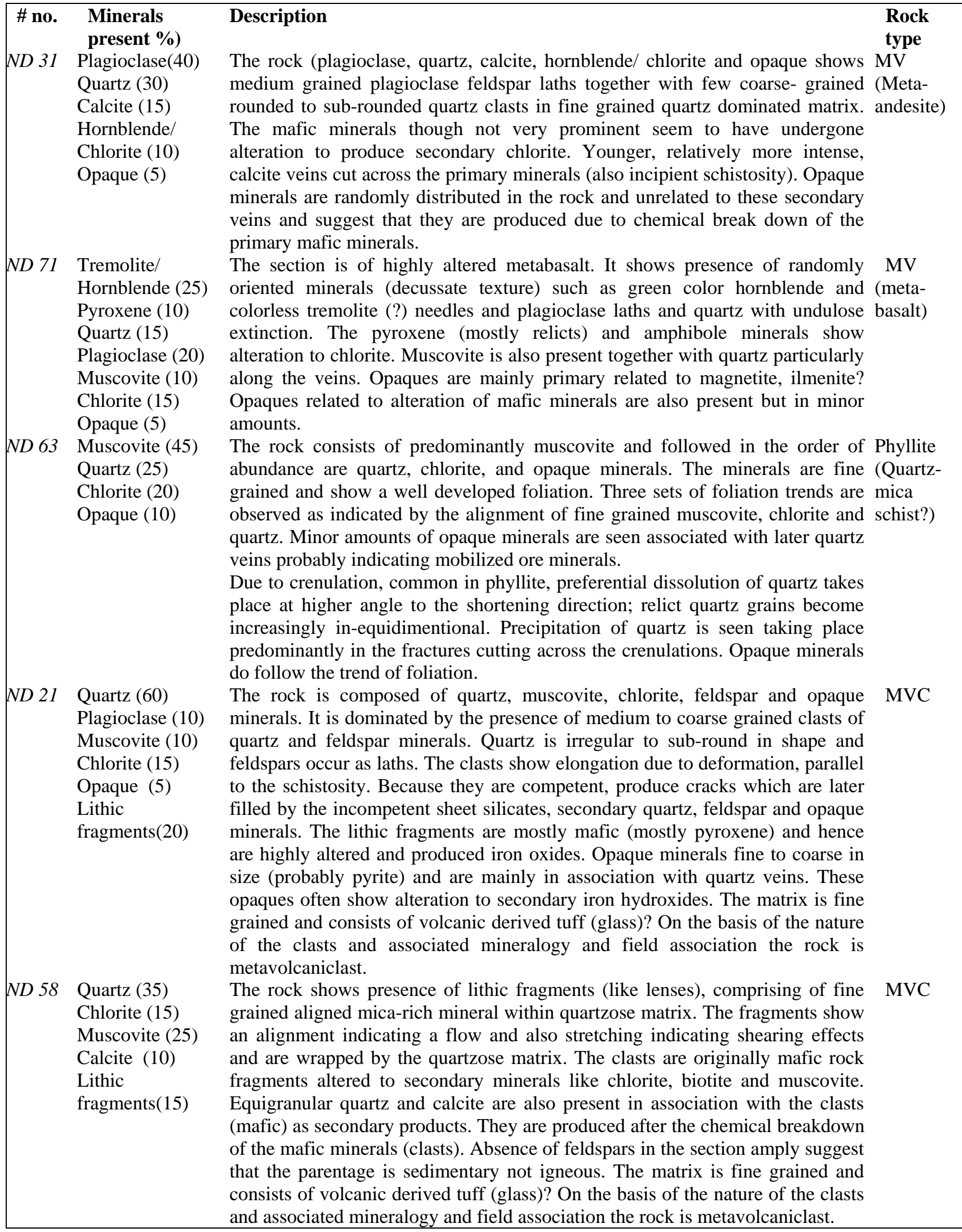




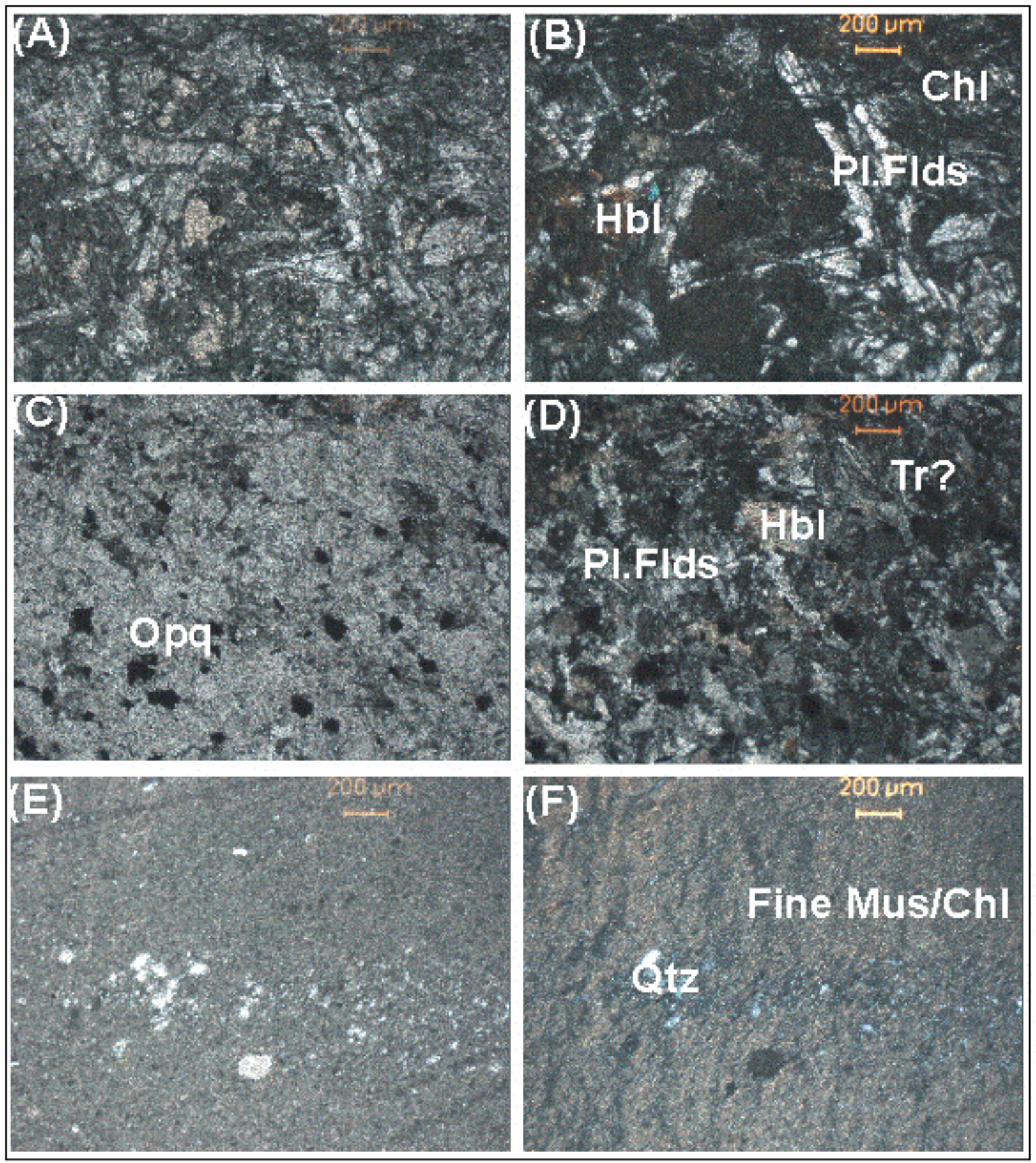

Figure 2. Microphotographs of basic metavolcanic (MV) and phyllite (MP) rocks. [MV rock (\#ND-31) (A) under PPL and (B) under cross, is relatively fresh with limited alteration showing decussate texture; MV rock (\#ND 71) (C) under PPL and (D) under cross, showing randomly distributed tremolite, muscovite, chlorite and opaques; Phyllite (\#ND 63) rock showing development of crenulation cleavage due to the alignment of fine grained muscovite and chlorite and is cut across by the later quarts vein (F) under PPL and (G) under cross position; (Note: Hbl- Hornblende; Chl- Chlorite; Pl. Felds- Plagioclase Feldspar; Tre Tremolite; Opq-Opaque;Qtz-Quartz; Mus-Muscovite)] 

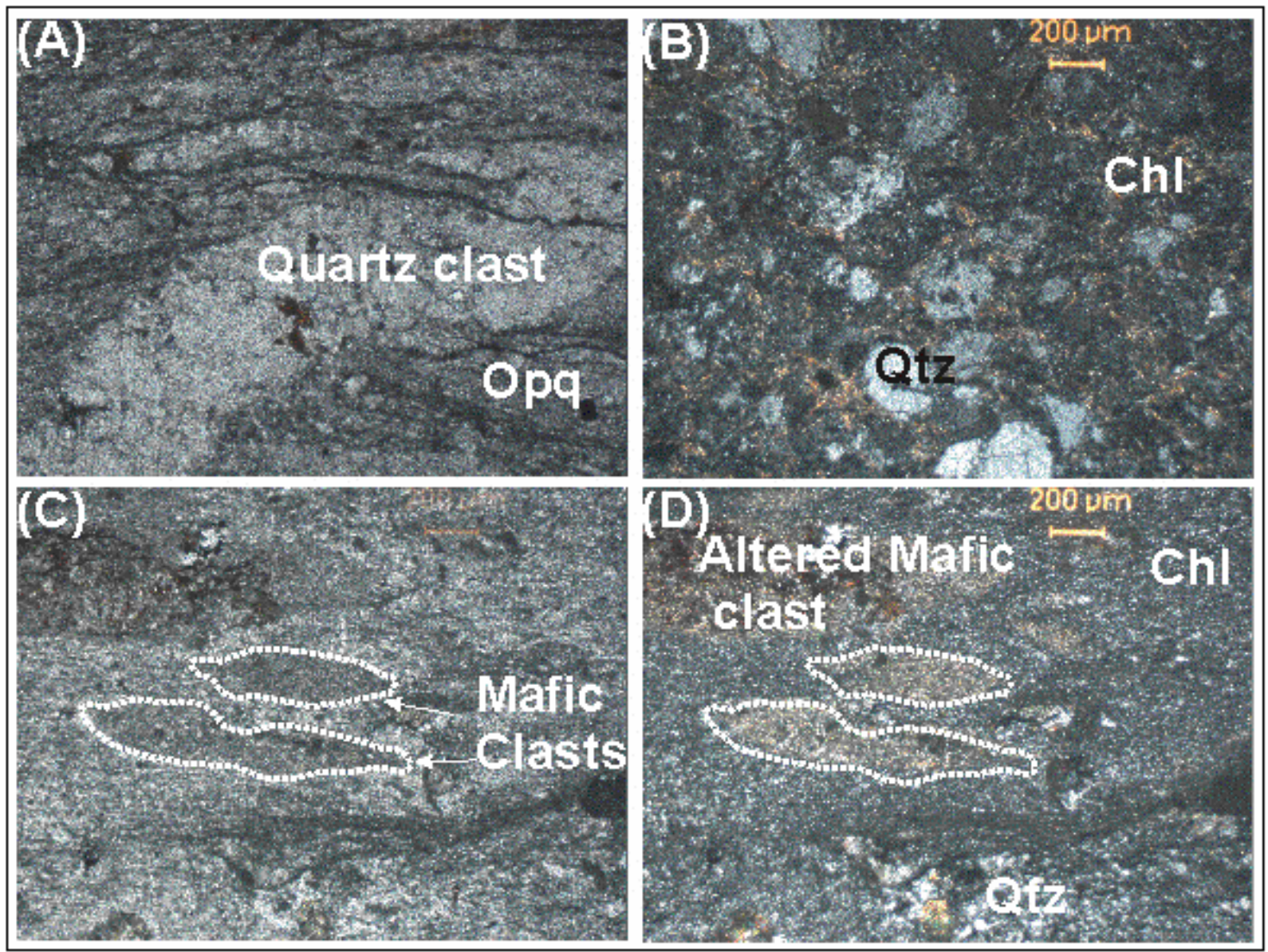

Figure 3. Microphotographs of metavolcaniclastic (MVC) rock [\#ND 21, (A) under PPL and (B) under cross, showing presence of a coarse grained highly fractured quartz clast set in a fine grained tuffaceous (glass?) matrix; \#ND 58, (C) under PPL and (D) under cross, showing elliptical, stretched and partially altered lithic fragments of mafic composition set in a fine grained tuffaceous (glass?) matrix (Note: Opq=Opaque; Chl-Chlorite; Qtz-Quartz).

\subsection{Rock Geochemistry}

Major oxide data indicates significant variation in major element concentrations in the three rock types (Table.2). Metavolcanic rocks show maximum values for $\mathrm{MgO}$ (upto 14\%), $\mathrm{Fe}_{2} \mathrm{O}_{3}$ (upto 13.3\%), and $\mathrm{CaO}$ (upto 10.39\%). Similarly metavolcaniclastic rocks show maximum values for $\mathrm{SiO}_{2}$ (upto 70\%), $\mathrm{Al}_{2} \mathrm{O}_{3}$ (upto 18\%) and $\mathrm{Na}_{2} \mathrm{O}$ (upto 9\%). In the case of metapelites, though $\mathrm{SiO}_{2}$ and $\mathrm{Al}_{2} \mathrm{O}_{3}$ and $\mathrm{MgO}$ values range up to $70 \%, 17 \%$ and $10 \%$ respectively, they show very low values for $\mathrm{CaO}$ (0.2 to $1 \%$ ) and $\mathrm{Na}_{2} \mathrm{O}$ (0.1 to 2\%). Among different oxides, $\mathrm{MgO}$ and $\mathrm{CaO}$ show inverse relation with $\mathrm{SiO}_{2}$ (Fig.4). $\mathrm{K}_{2} \mathrm{O}$ and $\mathrm{Na}_{2} \mathrm{O}$ values on the other hand show large variation in values and at the same time, do not suggest any particular pattern. 
Table 2. Major oxide data (wt\%) of Negash metamorphites, Tigray, northern Ethiopia.

\begin{tabular}{|c|c|c|c|c|c|c|c|c|c|c|c|}
\hline $\begin{array}{l}\text { S.No. } \\
\text { Meta }\end{array}$ & $\begin{array}{l}\text { \# no. } \\
\text { Icanic Ro }\end{array}$ & $\begin{array}{l}\mathrm{SiO}_{2} \\
\mathrm{ks}\end{array}$ & $\mathbf{A l}_{2} \mathbf{O}_{3}$ & $\begin{array}{l}\text { Total Fe } \\
\text { as } \mathrm{Fe}_{2} \mathrm{O}_{3}\end{array}$ & MnO & MgO & $\mathrm{CaO}$ & $\mathrm{Na}_{2} \mathrm{O}$ & $\mathbf{K}_{2} \mathbf{O}$ & $\mathrm{TiO}_{2}$ & $\mathbf{P}_{2} \mathbf{O}_{5}$ \\
\hline 1 & ND13 & 66.03 & 15.30 & 4.91 & 0.08 & 1.76 & 3.35 & 3.71 & 1.94 & 0.50 & 0.15 \\
\hline 2 & ND15 & 60.70 & 18.20 & 5.44 & 0.08 & 1.95 & 3.26 & 5.20 & 2.02 & 0.69 & 0.21 \\
\hline 3 & ND16 & 65.85 & 14.32 & 4.22 & 0.09 & 1.61 & 3.83 & 5.61 & 0.65 & 0.45 & 0.16 \\
\hline 4 & ND26 & 60.89 & 17.16 & 9.39 & b.d.l. & 1.15 & 0.20 & 0.10 & 5.18 & 0.92 & 0.12 \\
\hline 5 & ND27 & 50.03 & 15.14 & 13.30 & 0.25 & 3.22 & 10.39 & 2.55 & 0.10 & 1.40 & 0.15 \\
\hline 6 & ND28 & 62.46 & 15.51 & 7.23 & 0.11 & 2.91 & 1.51 & 5.33 & 1.21 & 0.87 & 0.14 \\
\hline 7 & ND31 & 63.39 & 12.41 & 6.15 & 0.15 & 3.70 & 5.49 & 3.53 & 0.70 & 0.63 & 0.12 \\
\hline 8 & ND32b & 55.93 & 15.84 & 6.85 & 0.15 & 4.58 & 1.89 & 4.65 & 1.29 & 0.68 & 0.18 \\
\hline 9 & ND51A & 51.17 & 16.02 & 8.90 & 0.12 & 6.25 & 7.14 & 3.67 & 0.51 & 0.56 & 0.10 \\
\hline 10 & ND68 & 49.88 & 18.68 & 11.64 & 0.07 & 6.81 & 0.34 & 4.44 & 0.91 & 0.69 & 0.18 \\
\hline 11 & ND71 & 50.96 & 14.82 & 7.73 & 0.18 & 13.74 & 3.19 & 4.08 & 0.07 & 0.67 & 0.11 \\
\hline 12 & ND74 & 48.38 & 17.01 & 7.85 & 0.15 & 12.44 & 2.56 & 5.41 & 0.15 & 0.50 & 0.10 \\
\hline 13 & ND75 & 49.95 & 17.02 & 10.28 & 0.21 & 7.24 & 5.18 & 5.58 & 0.10 & 0.69 & 0.13 \\
\hline 14 & ND76 & 50.20 & 17.30 & 8.88 & 0.16 & 9.45 & 3.94 & 5.91 & 0.10 & 0.67 & 0.10 \\
\hline \multicolumn{12}{|c|}{ Metavolcaniclastic Rock } \\
\hline 15 & ND1 & 65.43 & 14.19 & 7.27 & 0.09 & 1.37 & 0.54 & b.d.l. & 5.98 & 0.97 & 0.27 \\
\hline 16 & ND5 & 69.47 & 13.30 & 4.00 & 0.04 & 0.39 & 2.04 & 5.87 & 1.78 & 0.40 & 0.14 \\
\hline 17 & ND6 & 57.91 & 15.11 & 7.33 & 0.08 & 2.44 & 3.29 & 8.72 & 0.18 & 0.72 & 0.15 \\
\hline 18 & ND18 & 57.57 & 17.83 & 7.18 & 0.11 & 3.19 & 2.03 & 4.10 & 1.96 & 1.03 & 0.42 \\
\hline 19 & ND21 & 63.95 & 14.77 & 4.32 & 0.05 & 0.52 & 3.15 & 7.01 & 1.56 & 0.56 & 0.18 \\
\hline 20 & ND33 & 65.80 & 14.12 & 5.27 & 0.08 & 3.00 & 1.56 & 6.59 & 0.58 & 0.60 & 0.18 \\
\hline 21 & ND39 & 70.49 & 13.71 & 4.71 & 0.06 & 1.77 & 0.26 & 6.69 & 0.05 & 0.44 & 0.14 \\
\hline 22 & ND51 & 62.03 & 14.14 & 6.02 & 0.21 & 5.79 & 0.86 & 5.12 & 0.05 & 0.69 & 0.15 \\
\hline 23 & ND57 & 65.88 & 14.95 & 5.35 & 0.13 & 1.17 & 4.81 & 2.42 & 2.50 & 0.49 & 0.20 \\
\hline 24 & ND58 & 65.10 & 14.50 & 5.56 & 0.08 & 1.73 & 3.11 & 5.05 & 1.10 & 0.47 & 0.17 \\
\hline 25 & ND66 & 64.48 & 14.52 & 10.44 & 0.03 & 1.00 & 0.20 & 0.10 & 4.40 & 0.92 & 0.12 \\
\hline 26 & ND72 & 68.19 & 16.15 & 5.04 & b.d.l. & 0.72 & 0.20 & 0.10 & 4.43 & 0.87 & 0.05 \\
\hline 27 & ND98 & 66.46 & 13.67 & 7.95 & 0.05 & 3.31 & 0.25 & 0.49 & 2.77 & 0.68 & 0.13 \\
\hline 28 & ND99 & 62.71 & 17.92 & 7.06 & 0.11 & 2.97 & 0.33 & 2.43 & 3.06 & 0.62 & 0.13 \\
\hline \multicolumn{12}{|c|}{ Phyllite } \\
\hline 29 & ND42 & 59.61 & 14.20 & 6.03 & 0.11 & 2.22 & 6.30 & 1.62 & 2.45 & 0.51 & 0.15 \\
\hline 30 & ND45 & 65.19 & 13.63 & 6.54 & 0.10 & 2.71 & 2.04 & 4.53 & 1.25 & 0.58 & 0.15 \\
\hline 31 & ND49 & 58.07 & 19.09 & 6.96 & 0.08 & 4.02 & 0.78 & 1.92 & 3.32 & 0.79 & 0.22 \\
\hline 32 & ND55 & 62.75 & 16.30 & 8.16 & 0.03 & 3.25 & 0.20 & 0.10 & 3.29 & 0.91 & 0.06 \\
\hline 33 & ND55A & 69.56 & 14.39 & 6.38 & 0.18 & 1.08 & 0.95 & 1.68 & 1.62 & 0.46 & 0.18 \\
\hline 34 & ND63 & 54.94 & 17.04 & 6.45 & b.d.l. & 9.97 & 0.27 & b.d.l. & 4.61 & 0.93 & 0.18 \\
\hline 35 & ND65 & 67.63 & 14.18 & 7.58 & 0.03 & 0.84 & 0.20 & 0.10 & 3.41 & 1.02 & 0.08 \\
\hline 36 & ND72A & 69.92 & 11.52 & 5.28 & 0.06 & 1.17 & 3.12 & 3.70 & 1.65 & 0.47 & 0.14 \\
\hline 37 & ND96 & 67.74 & 13.29 & 8.06 & 0.05 & 3.39 & 0.26 & 0.48 & 2.77 & 0.69 & 0.13 \\
\hline 38 & ND100 & 64.91 & 17.14 & 5.49 & 0.03 & 1.26 & 0.20 & 0.12 & 4.75 & 0.92 & 0.05 \\
\hline \multicolumn{12}{|l|}{ Slate } \\
\hline 39 & ND60 & 66.24 & 14.62 & 8.22 & 0.03 & 1.36 & 0.31 & 0.17 & 4.06 & 0.91 & 0.20 \\
\hline
\end{tabular}




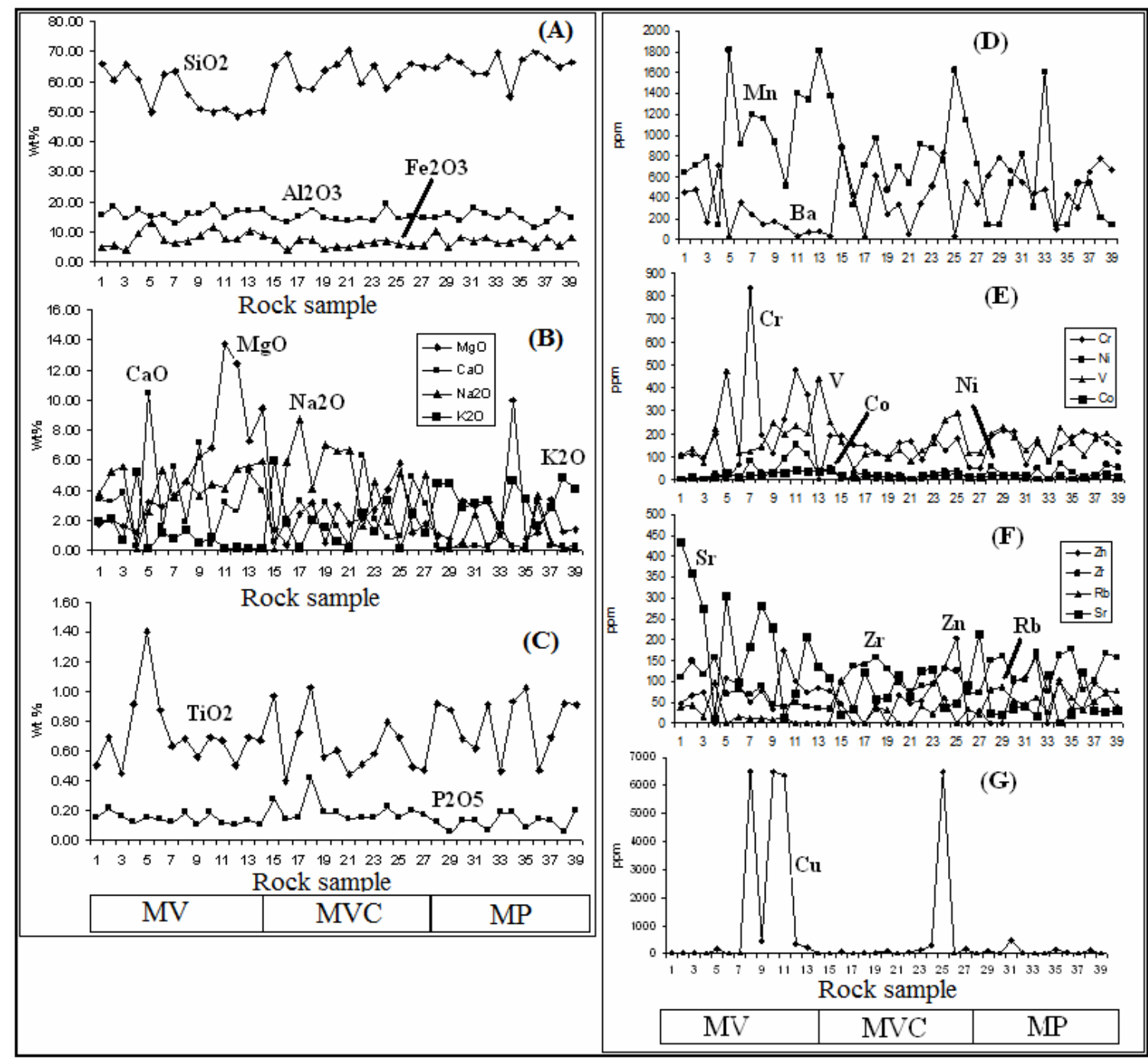

Figure 4. Showing variation in major oxide (wt\%) and trace element (ppm) concentrations in metavolcanic (\# 1-14), metavolcaniclastic (\#15-28), phyllite (\#29-38) and slate (\#39): (A) $\mathrm{SiO}_{2}, \mathrm{Al}_{2} \mathrm{O}_{3}$ and $\mathrm{Fe}_{2} \mathrm{O}_{3}$; (B) $\mathrm{MgO}, \mathrm{CaO}, \mathrm{Na}_{2} \mathrm{O}$ and $\mathrm{K}_{2} \mathrm{O}$; (C) $\mathrm{TiO}_{2}$ and $\mathrm{P}_{2} \mathrm{O}_{5}$; (D) $\mathrm{Ba}$ and $\mathrm{Mn}$; (E) Cr, Ni, V and Co; (F) Zn, Zr, Rb and Sr; and (G) Cu.

Among various trace elements analysed (Table.3), only $\mathrm{Cu}, \mathrm{Zn}, \mathrm{Ni}, \mathrm{Co}, \mathrm{Cr}, \mathrm{V}, \mathrm{Zr}, \mathrm{Ba}, \mathrm{Rb}, \mathrm{Sr}$ show large variation in the three rock types. Few samples show above $6500 \mathrm{ppm}$ for copper in both MV and MVC and up to 170 in MP. Other base metals, such as zinc and lead are conspicuously low 24-205 ppm and 10-20 ppm respectively. Ba values are relatively higher in MVC and MP (> 800 ppm) compared to MV. Other elements like Ni, Cr and V are expectedly show higher values upto 151, 838 and 474 ppm respectively in MV and Zr values (179 ppm) in MP (Fig. 4). Similar values for trace elements in different rocks were also reported by Alene et al. (2000) and Dwivedi (2003). 
Table 3. Trace element data (ppm) of Negash metamorphites, Tigray, northern Ethiopia.

\begin{tabular}{|c|c|c|c|c|c|c|c|c|c|c|c|c|}
\hline \multicolumn{13}{|c|}{ Metavolcanic Rocks } \\
\hline 1 & ND13 & 460 & 1 & 1 & 108 & 638 & 1 & 40 & 434 & 103 & 49 & 111 \\
\hline 2 & ND15 & 478 & 12 & 23 & 111 & 716 & 1 & 44 & 361 & 136 & 67 & 150 \\
\hline 3 & ND16 & 175 & 1 & 44 & 100 & 792 & 1 & 16 & 275 & 73 & 73 & 117 \\
\hline 4 & ND26 & 706 & 11 & 1 & 197 & 150 & 26 & 99 & 11 & 223 & 1 & 158 \\
\hline 5 & ND27 & 23 & 30 & 151 & 1 & 1815 & 1 & 1 & 306 & 474 & 108 & 72 \\
\hline 6 & ND28 & 355 & 11 & 1 & 66 & 913 & 1 & 16 & 99 & 114 & 93 & 81 \\
\hline 7 & ND31 & 245 & 18 & 1 & 838 & 1204 & 81 & 12 & 183 & 122 & 51 & 68 \\
\hline 8 & ND32b & 149 & 18 & 6500 & 193 & 1160 & 27 & 11 & 283 & 143 & 79 & 89 \\
\hline 9 & ND51A & 171 & 30 & 456 & 114 & 934 & 32 & 10 & 229 & 248 & 34 & 47 \\
\hline 10 & ND68 & 117 & 32 & 6500 & 264 & 511 & 92 & 14 & 14 & 200 & 175 & 38 \\
\hline 11 & ND71 & 37 & 43 & 6359 & 479 & 1405 & 151 & 1 & 72 & 237 & 100 & 50 \\
\hline 12 & ND74 & 70 & 36 & 342 & 372 & 1340 & 111 & 1 & 209 & 204 & 74 & 38 \\
\hline 13 & ND75 & 79 & 38 & 209 & 1 & 1806 & 23 & 1 & 138 & 442 & 84 & 36 \\
\hline 14 & ND76 & 35 & 46 & 1 & 188 & 1375 & 50 & 1 & 111 & 251 & 79 & 34 \\
\hline \multicolumn{13}{|c|}{ Metavolcaniclastic Rock } \\
\hline 15 & ND1 & 880 & 16 & 1 & 195 & 881 & 1 & 104 & 20 & 167 & 48 & 97 \\
\hline 16 & ND5 & 436 & 1 & 75 & 154 & 330 & 17 & 33 & 35 & 47 & 1 & 137 \\
\hline 17 & ND6 & 30 & 16 & 1 & 149 & 715 & 33 & 1 & 123 & 111 & 1 & 139 \\
\hline 18 & ND18 & 614 & 17 & 25 & 119 & 976 & 1 & 36 & 57 & 120 & 49 & 159 \\
\hline 19 & ND21 & 250 & 11 & 27 & 100 & 475 & 22 & 32 & 62 & 97 & 1 & 130 \\
\hline 20 & ND33 & 336 & 12 & 90 & 161 & 701 & 19 & 1 & 118 & 126 & 67 & 97 \\
\hline 21 & ND39 & 51 & 1 & 1 & 168 & 545 & 1 & 1 & 66 & 84 & 49 & 76 \\
\hline 22 & ND51 & 35 & 25 & 6500 & 178 & 1625 & 36 & 1 & 49 & 293 & 205 & 126 \\
\hline 23 & ND57 & 546 & 12 & 1 & 55 & 1145 & 1 & 35 & 92 & 114 & 1 & 74 \\
\hline 24 & ND58 & 348 & 13 & 155 & 51 & 725 & 1 & 21 & 216 & 120 & 30 & 74 \\
\hline 25 & ND66 & 613 & 16 & 1 & 196 & 150 & 57 & 81 & 26 & 204 & 1 & 152 \\
\hline 26 & ND72 & 793 & 15 & 110 & 215 & 150 & 19 & 87 & 21 & 233 & 1 & 160 \\
\hline 27 & ND98 & 664 & 18 & 1 & 210 & 541 & 16 & 54 & 36 & 187 & 99 & 105 \\
\hline 28 & ND99 & 553 & 19 & 474 & 65 & 819 & 1 & 45 & 42 & 130 & 110 & 103 \\
\hline \multicolumn{13}{|c|}{ Phyllite } \\
\hline 29 & ND42 & 342 & 22 & 73 & 87 & 921 & 1 & 41 & 126 & 128 & 54 & 90 \\
\hline 30 & ND45 & 516 & 17 & 131 & 190 & 868 & 23 & 23 & 131 & 159 & 97 & 93 \\
\hline 31 & ND49 & 826 & 19 & 278 & 126 & 766 & 37 & 61 & 39 & 259 & 132 & 130 \\
\hline 32 & ND55 & 441 & 1 & 39 & 161 & 311 & 51 & 63 & 19 & 177 & 159 & 169 \\
\hline 33 & ND55A & 473 & 1 & 1 & 85 & 1605 & 1 & 28 & 115 & 77 & 1 & 75 \\
\hline 34 & ND63 & 97 & 21 & 1 & 140 & 150 & 69 & 98 & 1 & 227 & 104 & 162 \\
\hline 35 & ND65 & 430 & 1 & 170 & 187 & 150 & 33 & 63 & 23 & 162 & 34 & 179 \\
\hline 36 & ND72A & 306 & 11 & 22 & 211 & 543 & 1 & 32 & 125 & 108 & 34 & 80 \\
\hline 37 & ND96 & 648 & 20 & 1 & 195 & 539 & 16 & 52 & 32 & 176 & 96 & 104 \\
\hline 38 & ND100 & 777 & 25 & 141 & 161 & 212 & 68 & 74 & 27 & 201 & 75 & 168 \\
\hline \multicolumn{13}{|l|}{ Slate } \\
\hline 39 & ND60 & 669 & 14 & 1 & 125 & 150 & 54 & 77 & 32 & 162 & 40 & 159 \\
\hline
\end{tabular}

According to Dwivedi (2003) (on ten samples) Cu values varied from 1.44 to $2.6 \%$ in $\mathrm{MV}$ and 26 to 6440 ppm in phyllite and alteration zones. Lead concentrations are high in metapelites and varied from 288 to $5380 \mathrm{ppm}$. Zinc is interestingly low and varied from 16 to $254 \mathrm{ppm}$ in the area. Iron from 2.53 to $42.62 \%$ particularly is very high in alteration zones. Manganese varied 
from 43 to 2012; nickel and cobalt from 16 to 51 and 8 to 65 ppm respectively. Silver and arsenic are also reported from the study area, the values varied from 1.4 to 21.3 and 24 to 145 ppm respectively (Dwivedi, 2003). According to Alene et al. (2000), Ni varied from 22 to 146 ppm in metavolcanic rock and 14 to 36 in metavolcaniclasts; Co from 37 to 45 in metavolcanics and 12 to $30 \mathrm{ppm}$ in metavolcaniclasts.

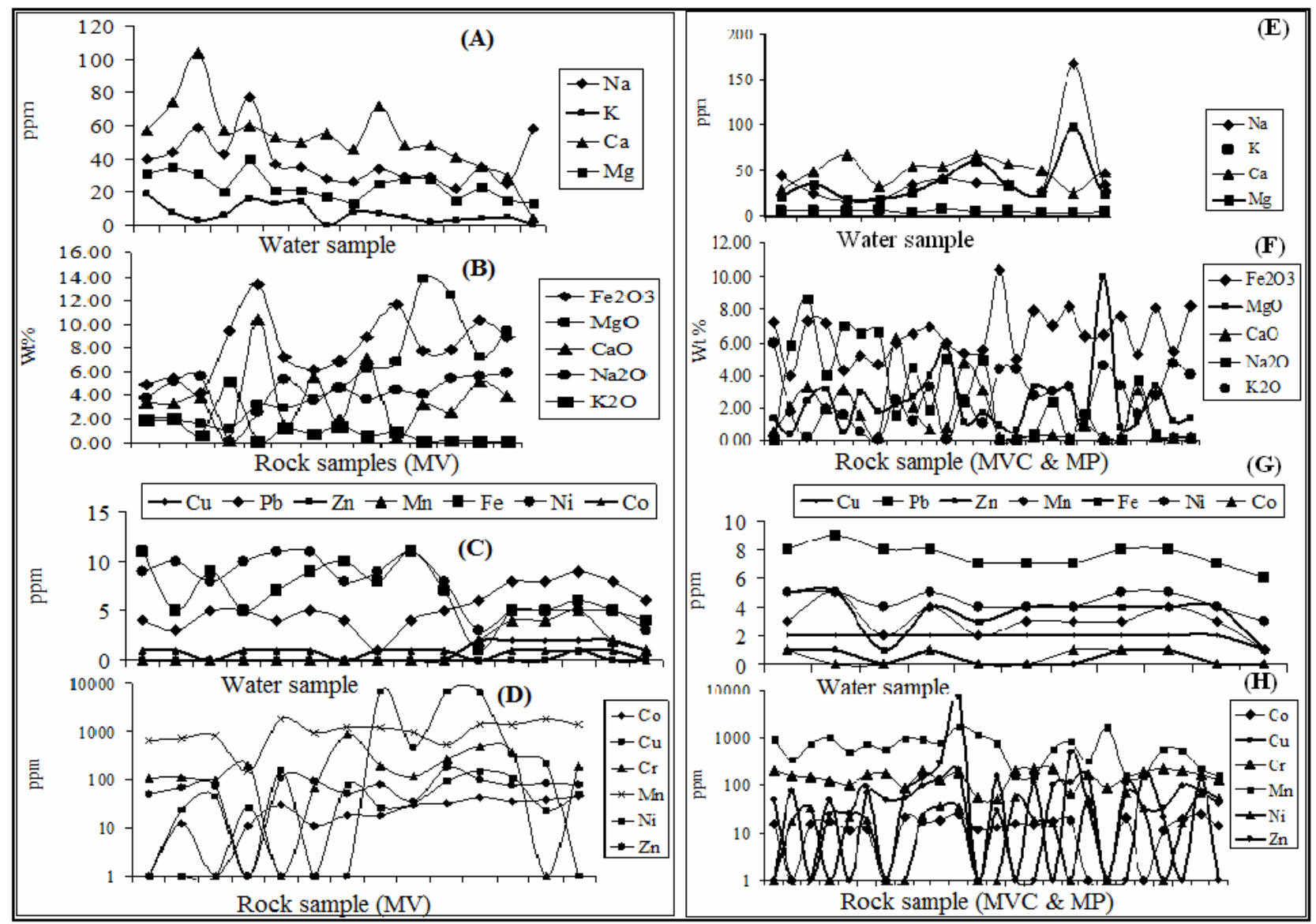

Figure 5. Major and trace elements variation in groundwater samples collected from MV, MVC and MP rock dominated areas: (A) major element concentration (ppm) in groundwater (\#1-16) from MV area; (B) major oxides (wt\%) in rock (MV); (C) trace element concentration (ppm) in groundwater (\#1-16) from MV area and (D) trace element concentration (ppm) in the rock (MV); (E) major element concentration (ppm) in groundwater (\# 17-27) from MVC and MP area; (F) major oxides (wt\%) in the rock (MVC \& MP); (G) trace element concentration (ppm) in groundwater (\# 17-27) from MVC \& MP area and (H) trace element concentration (ppm) in the rock (MVC \& MP). 
Table 4. Hydrogeochemical data (ppm), Negash, Tigray, northern Ethiopia (Bheemalingeswara and Nata, 2006).

\begin{tabular}{|c|c|c|c|c|c|c|c|c|c|c|c|c|c|c|c|}
\hline S.No & \# No. & Rock & $\begin{array}{l}\text { E.C } \\
(\mu S)\end{array}$ & $\begin{array}{r}\text { TDS } \\
(\mathrm{ppm})\end{array}$ & SAR & $\begin{array}{l}\text { Hard- } \\
\text { ness }\end{array}$ & $\mathrm{Na}$ & $\mathbf{K}$ & $\mathbf{C a}$ & Mg & $\mathbf{C u}$ & $\mathbf{P b}$ & Mn & $\mathbf{F e}$ & $\mathrm{Ni}$ \\
\hline 1 & NR2 & MV & -- & --- & 6 & 270 & 40 & 19 & 57 & 31 & bd & 4 & bd & 11 & 9 \\
\hline 2 & NR4 & MV & --- & --- & 6 & 329 & 44 & 8 & 74 & 35 & bd & 3 & bd & 5 & 10 \\
\hline 3 & NR7 & MV & --- & --- & 7 & 387 & 59 & 3 & 104 & 31 & bd & 5 & bd & 9 & 8 \\
\hline 4 & NR9 & MV & --- & --- & 7 & 225 & 43 & 6 & 57 & 20 & bd & 5 & bd & 5 & 10 \\
\hline 5 & NR14 & MV & --- & --- & 13 & 229 & 77 & 16 & 60 & 40 & bd & 4 & bd & 7 & 11 \\
\hline 6 & NR22 & MV & --- & --- & 7 & 221 & 37 & 13 & 53 & 21 & bd & 5 & bd & 9 & 11 \\
\hline 7 & NR25 & MV & --- & --- & 6 & 219 & 35 & 14 & 50 & 21 & bd & 4 & bd & 10 & 8 \\
\hline 8 & NR28 & MV & --- & --- & 5 & 207 & 28 & 0 & 55 & 17 & bd & 1 & bd & 8 & 9 \\
\hline 9 & NR30 & MV & --- & --- & 5 & 168 & 26 & 8 & 46 & 13 & bd & 4 & bd & 11 & 11 \\
\hline 10 & NR31 & MV & --- & --- & 5 & 283 & 34 & 7 & 72 & 25 & bd & 5 & bd & 7 & 8 \\
\hline 11 & NR34 & MV & 420 & 294 & 6 & 216 & 29 & 5 & 48 & 28 & 2 & 6 & 2 & 1 & 3 \\
\hline 12 & NR35 & MV & 600 & 420 & 5 & 235 & 29 & 2 & 48 & 28 & 2 & 8 & 4 & 5 & 5 \\
\hline 13 & NR40 & MV & 390 & 273 & 4 & 164 & 22 & 3 & 41 & 15 & 2 & 8 & 4 & 5 & 5 \\
\hline 14 & NR41 & MV & 410 & 287 & 6 & 182 & 35 & 4 & 35 & 23 & 2 & 9 & 5 & 6 & 5 \\
\hline 15 & NR56 & MV & 350 & 245 & 5 & 134 & 25 & 5 & 29 & 15 & 2 & 8 & 2 & 5 & 5 \\
\hline 16 & NR57 & MV & 150 & 105 & 20 & 63 & 58 & 0 & 4 & 13 & 1 & 6 & 1 & 4 & 3 \\
\hline 17 & NR43 & $\mathrm{MVC}+\mathrm{MP}$ & 340 & 238 & 7 & 137 & 31 & 7 & 27 & 17 & 2 & 8 & 3 & 5 & 5 \\
\hline 18 & NR44 & $\mathrm{MVC}+\mathrm{MP}$ & 470 & 329 & 9 & 156 & 44 & 6 & 28 & 21 & 2 & 9 & 5 & 5 & 5 \\
\hline 19 & NR46 & $\mathrm{MVC}+\mathrm{MP}$ & 590 & 413 & 4 & 264 & 24 & 6 & 48 & 35 & 2 & 8 & 2 & 1 & 4 \\
\hline 20 & NR47 & $\mathrm{MVC}+\mathrm{MP}$ & 330 & 231 & 2 & 241 & 16 & 6 & 67 & 18 & 2 & 8 & 4 & 4 & 5 \\
\hline 21 & NR48 & $\mathrm{MVC}+\mathrm{MP}$ & 410 & 287 & 3 & 154 & 17 & 7 & 32 & 18 & 2 & 7 & 2 & 3 & 4 \\
\hline 22 & NR49 & $\mathrm{MVC}+\mathrm{MP}$ & 710 & 497 & 5 & 242 & 34 & 3 & 54 & 26 & 2 & 7 & 3 & 4 & 4 \\
\hline 23 & NR50 & $\mathrm{MVC}+\mathrm{MP}$ & 810 & 567 & 6 & 303 & 40 & 8 & 54 & 41 & 2 & 7 & 3 & 4 & 4 \\
\hline 24 & NR51 & $\mathrm{MVC}+\mathrm{MP}$ & 1140 & 798 & 5 & 414 & 36 & 5 & 67 & 60 & 2 & 8 & 3 & 4 & 5 \\
\hline 25 & NR52 & $\mathrm{MVC}+\mathrm{MP}$ & 740 & 518 & 5 & 278 & 33 & 6 & 57 & 33 & 2 & 8 & 4 & 4 & 5 \\
\hline 26 & NR53 & $\mathrm{MVC}+\mathrm{MP}$ & 590 & 413 & 4 & 232 & 27 & 4 & 50 & 26 & 2 & 7 & 3 & 4 & 4 \\
\hline 27 & NR54 & $\mathrm{MVC}+\mathrm{MP}$ & 970 & 679 & 22 & 460 & 168 & 4 & 25 & 97 & 1 & 6 & 1 & 1 & 3 \\
\hline
\end{tabular}

Note: bd: below detection; $\mathrm{MV}=$ Metavolcanic; $\mathrm{MP}=$ Metapelite; $\mathrm{MVC}=$ Metavolcaniclast

\subsection{Water Geochemistry}

Na shows high values as compared to other major ions, varying from 16 to 168 ppm, Ca from 4 to $104 \mathrm{ppm}$, Mg from 13 to $97 \mathrm{pm}$ and $\mathrm{K}<19 \mathrm{ppm}$. Na and $\mathrm{Mg}$ shows high values in groundwater collected from MVC and MP dominated area. On the other hand, Ca shows higher values in the water collected from MV (Table.4, Fig. 5). Potassium shows low values and insignificant variation. Among trace elements, Fe values vary from 1 to $12, \mathrm{Ni} \sim 13$ and $\mathrm{Pb} 1$ to 9. Other elements such as $\mathrm{Mn}$ vary from $<5, \mathrm{Cu}<2$ and $\mathrm{Co}$ and $\mathrm{Zn}$ are in below detection level. 
$\mathrm{Fe}, \mathrm{Ni}$ and $\mathrm{Mn}$ show higher values in the samples collected from MV dominated area and $\mathrm{Pb}, \mathrm{Ni}$ and Mn in those collected from MVC and MP dominated area.

\section{DISCUSSION}

\subsection{Petrography}

On the basis of the dominant mineral phases that are present in different rock types in the study area and their textures, the rocks are named as metavolcanic, metavolcaniclastic, phyllite and slate. The presence of chlorite and muscovite, and development of foliation indicates low grade metamorphism in the area. At the same time, development of schistosity at places is observed due to the localized effects but only in MVC, MP as compared to MV. On the basis of the nature of alignment, texture, size and type of minerals identified in these rocks, it is possible to conclude that the rocks have experienced only low grade greenschist facies metamorphism. Minerals like tremolite and biotite (rare), though their identification is somewhat difficult because they are mostly fine grained, are developed in some of the sections. They are not common minerals and possibly developed due to the increased temperatures locally provided by the later intrusive bodies or hydrothermal activity or shearing.

Among the three types of rocks such as MV, MVC and MP, metavolcanics being dominated by metabasalts clearly shows fine grained matrix with few coarse mafic and plagioclase minerals (Figs.2A-D) and corresponding geochemistry in figure 4 and tables 1 and 2. Similarly, MP is characterized by the fine-grained matrix and with well developed foliation and crenulations (Fig.2E-F) and corresponding geochemistry in figure 4 and tables 1 and 2. In the case of MVC, the rocks show variation in matrix as well as composition of clasts (Fig.3A-D) and geochemistry (Fig.4 and Tables 1 and 2). Matrix varies from grey/ white colored volcanic tuff ( \pm fine argillaceous) with fine clay/ash/muscovite to green colored fine grained mafic composition. There are also indications of the presence of glassy material (glass shards?) in the section indicating volcanic source. The clasts on the other hand, vary from dominant quartz, feldspar to rare green colored mafic rock fragments and show angular, rounded, sub-rounded and irregular shapes. Petrographic data together with the field observation (which do not indicate proper evidence of sedimentation) indicate that the clasts and matrix are primarily related to volcanic activity and probably with limited sediment input. The clasts often show elongation/ stretching indicating shearing effects and are typically related to the shear zones in the field. The size 
variation of the clasts from east (coarse) to west (fine) in the study area seems to indicate the direction of the source of supply to be in the east. However, these rocks being subjected to later folding and faulting, such relationship needs to be established only after regional correlation. Secondary quartz is more prominent in metavolcaniclastic rock as compared to others. Quartz and calcite veins are common in all types of rocks and often cut across the schistosity and represent different episodes.

Among opaque minerals, pyrite is common often showing cubic outlines. It is also visible in hand specimen often showing alteration to limonite. Association of opaques within the primary minerals, alteration products and quartz and calcite veins of different generation indicates difference in their genesis and emplacement conditions. The first variety in association with primary minerals, is seen distributed randomly and in relation to the primary magmatic minerals e.g. magnetite, ilmenite (common in MV). The secondary variety is the one which is formed due to chemical breakdown of the primary mafic minerals (common in MV). The clasts of mafic variety in MVC also show similar alterations. The third is in association with the hydrothermal cross cutting quartz and calcite veins (Figs. 2A-D). In the case of MVC and MP, the opaques are mainly related to euxinic environment or hydrothermal activity. The pyrite related to euxinic environment is a sedimentary pyrite and is also quite visible in the hand specimen. The hydrothermal variety is fine-grained and associated with hydrothermal veins and is quite prominent in shear zones. Interestingly, chalcopyrite, though not identified under microscope, is the dominating sulfide ore mineral in shear zones as compared to pyrite as indicated by the presence of green malachite stains and anomalous concentrations for copper (Table 2). Absence of any indications of development of gossan, which is common in base metal sulfides, is quite conspicuous in the area. Anyone or more of the following reasons may explain the absence or non-development of gossan- i) the base metal mineralization is of very low grade, ii) pyrite mineral (dominantly gossan producing mineral) is very low among sulfides, iii) the mineralization is subsurface and not exposed for intense weathering, iv) the mineralization is shear zone- related and dispersed.

Finally, uplift of the basement rocks has facilitated meteoric water- rock interaction in addition to the hydrothermal solutions- rock interaction and has resulted in kaolinisation, sericitisation etc. So, the mineralogy and related textural properties suggest that the rocks have experienced 
low grade regional metamorphism and emplacement of granitic plutons have facilitated oreforming fluids that are dominant in the shear zones.

\subsection{Geochemistry of Basement Rocks and Mineralization}

Tectonic discrimination diagram (Fig.6) drawn between $\mathrm{TiO}_{2}$ and $\mathrm{Zr}$ for metavolcanic rocks suggests an island arc tectonic setting. Basic metavolcanic unit is the dominant unit among MV which is calc-alkaline in composition and related to volcanic arc setting environment (Alene et al., 2000). Major oxide data indicates lower values for $\mathrm{K}$

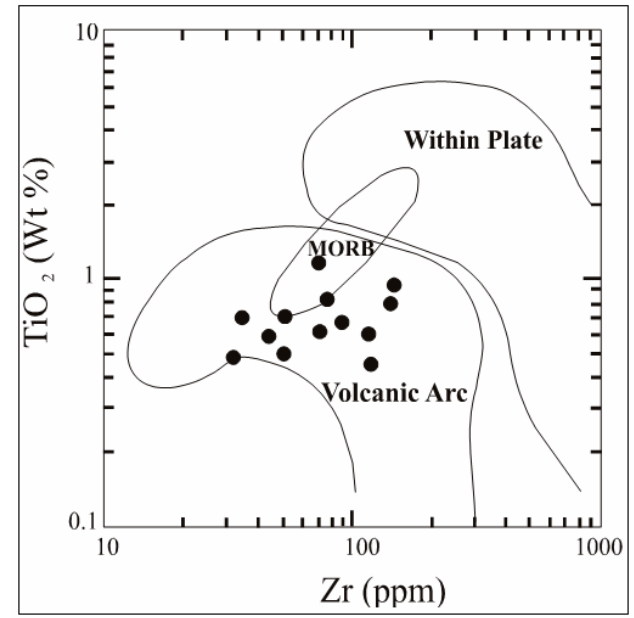
(Fig.4) suggesting that the metavolcanics are not only calc-alkaline in composition but also low -K type. Erratic behavior and low values of $\mathrm{K}$ seems to be a common feature in metamorphosed rocks due to the mobility of $\mathrm{K}$ either through diffusion, albitisation of plagioclase or loss due to mobility during metamorphism (Alene et al., 2000).

Figure 6. Tectonic setting discrimination diagram, metavolcanics of Negash (Pearce, 1980).

Phyllite rocks show high silica values with marginally increased $\mathrm{Al}_{2} \mathrm{O}_{3}$. Some of the samples show relatively higher values for Mg as compared to MV and MVC (Table.2). Higher values for Mg are ascribed to mineral chlorite. Significant variation in trace element content in phyllites is well reflected by the colors that it displays. The colors include grey, green, violet, and red. Higher values for iron in phyllite are ascribed to the dominantly present sedimentary pyrite. Along the shear zones, both in phyllites and MVC, the presence of grey or silvery white colored sericite indicating sericitisation is quite conspicuous. Sericitisation seems to indicate input of potassium (alkali metasomatism?) that is leached by hydrothermal solutions from the country rock MV which clearly indicate lower values for $\mathrm{K}^{+}$. Other elements like $\mathrm{Mn}$ and $\mathrm{Ba}$ though relatively high in phyllite, do not suggest any abnormal behavior and any trend.

In the case of metavolcaniclastics the major oxides $\mathrm{SiO}_{2}, \mathrm{Al}_{2} \mathrm{O}_{3}, \mathrm{MgO}$ and $\mathrm{Fe}_{2} \mathrm{O}_{3}$ vary in concentration significantly. They are mainly related to the clasts which vary in size (east to west) and composition and also to the varying matrix composition from tuffaceous to argillaceous and mixed. Some of the samples though indicate higher values for $\mathrm{Sr}, \mathrm{Ba}$ and $\mathrm{Mn}$ which are comparable to metavolcanics and higher than that of metasediments, are not consistent and does 
not indicate clearly the source of these rocks. Anomalous values for copper on the other hand are clearly related to the shear zone hydrothermal activity.

On the basis of the present and published petrological, geochemical and structural data, it is possible to construct a sequence of events that have taken place in the area. Sedimentation and development of linear sedimentary belts in intra oceanic basins (Tadesse, 1999) was accompanied by bimodal volcanism during Middle to Late Proterozoic times. The sediments together with volcanics have undergone low grade regional metamorphism. The younger intrusive plutonic marks the end of the tectonic activity and Proterozoic Era. They have facilitated the generation of hydrothermal solutions which have leached the metals from the rocks and transported to the sites of deposition i.e. structural weak zones. During the same time N-NE trending shear zones have developed and facilitated deposition of copper sulfide -bearing hydrothermal fluids particularly along the contacts among between metavolcanics, metasediments and MVC. It is indicated by the presence of malachite stains and anomalous concentrations of $\mathrm{Cu}$ (Table.2). Since the type and content of the metal depends on the nature of the source rock, the metals showing anomalous values for copper suggest the source as basic MV which is the dominating rock type in the area. Other base metals like lead and zinc as expected do not show high values in the area because of lack of the suitable source rocks such as felsic volcanics and thick sedimentary cover.

The absence of gossan and the presence of malachite and anomalous copper values (Table.2) with subordinate quantities of silver and gold (Dwivedi, 2003) particularly in shear zones indicate the presence of a shear zone-hosted copper sulfide mineralization. Interestingly, similar type of shear zone-controlled base metal mineralization (Zn up to 2-3\%) about 100-150 m wide with 5-6 km strike length near Abrha Atsbha about $10 \mathrm{~km}$ west of Negash is also reported. Ezana Mining Development PLC has obtained the license of the area and is undertaking exploration activities. Both the mineralizations are shear zone-controlled and are related to intrusive granitic plutons (Fig.1). Variation in the type of the base metal, copper in the study area (east) and zinc in Abrha Atsbha (west) is related to the source rock i.e. basic metavolcanics for $\mathrm{Cu}$ (dominant in Negash) and metarhyolite for Zn (dominant at Abrha Atsbha). Since shear zones being anomalous in the area and vary considerably in thickness and metal content, it needs to be studied in detail so as to quantify the metals and their economic significance. It is interesting to note that the quartz veins (of different generations?) in Negash area show N-NE trend similar to 
shear zones whereas at Abrha Atsbha in addition to N-NE trending quartz veins, there are E-W trending quartz veins parallel to Wukro fault. The veins trending N-NE are Zn-rich and E-W are barite rich.

Regarding tectonic setting, the rocks in the study area represent intra-oceanic arc sequences of northern Ethiopia (southern part of Arabian Nubian Shield) that have varied in lithological and geochemical characteristics (Tadesse, 1999) and are consistent with the arc accretion models as suggested for Sudan, Egypt and Saudi Arabia (Alene et al., 2000). The arc related tectonic setting together with bimodal volcanism though supports VMS type base metal mineralization, a shear-controlled base metal mineralization is identified in the study area on the basis of petrographic, structural and geochemical data.

\subsection{Geochemistry of Groundwater}

Water hardness, one of the important parameters used to evaluate natural water quality is generally known to be influenced chemically by dissolution of calcite and dolomite. But it can also be influenced by other rocks which have significant amount of $\mathrm{Ca}$ and $\mathrm{Mg}$-bearing soluble plagioclase feldspar and mafic minerals respectively. The proportion of $\mathrm{Ca}^{2+}$ and $\mathrm{Mg}^{2+}$ present in water can be used as an indicator of the geology of the aquifer. Calculated values for total hardness in 32 water samples range from 130 to $460 \mathrm{ppm}$. According to the hardness classification the majority of the samples from MP come under hard water category (Todd, 1980). Interestingly these values are comparable with high $\mathrm{Pb}$ values in MP. Geochemical affinity between $\mathrm{Pb}$ and hardness if any, need to be established. $\mathrm{Ca}$ and $\mathrm{Mg}$ ratios $(\mathrm{Ca} / \mathrm{Mg})$ range from 2.88 (MV and MVC) to 0.258 (MP). The lack of Ca-plagioclase and presence of Mg-rich chlorite in MP are related to the higher values for Mg in MP. Higher values for Ca in MV are related to epidote and plagioclase feldspar and in MVC to the plagioclase feldspar and mafic minerals-rich clasts (Figs. 5). Sodium, though is relatively high in the samples, it does not show a particular trend with reference to the rocks. Sodium absorption ratio (SAR) is another property of water that indicates sodium concentration and its possible effects on soil. The samples show significant variation in SAR values from 2-10 except two samples that are showing very high values about 20. It is known that higher amounts of sodium affects the soil by decreasing permeability and become toxic to plants (sodium poisoning). So, the soils either alkali (sodium with carbonate) or saline (sodium with chloride or sulphate) will not support proper plant 
growth. Hence the water is non-suitable for irrigation purpose (Fetter, 1994). According to TDS values the water type is fresh water type and fit for domestic use.

Since trace element data is limited, it is difficult to say whether the water particularly from shear zones is safe for drinking purposes or not. It is well known that the base metal mineralization, even low grade, can contribute trace elements $\mathrm{Cu}, \mathrm{Zn}, \mathrm{Pb}$ and others significantly to groundwater and influence their quality. The water geochemical data when compared with the water quality standard values (maximum limit) as proposed by World Health Organization (WHO, 1993) (Fe0.3 ppm; Ni -0.02; Pb-0.01; Mn -0.5; Cu-2.0 \& Zn 3.0), some of the trace elements like Ni, Pb and Fe show much higher in concentration ( $>10 \mathrm{ppm})$ than the permissible levels. These increased values are related to the alteration zones where the incidence of base and other metals are relatively higher. Among $\mathrm{Fe}, \mathrm{Ni}$ and $\mathrm{Pb}$, iron and nickel are related to $\mathrm{MV}$ and $\mathrm{MVC}$; and lead to MP. Both Fe and Ni seem to be related to the primary mafic mineralogy such as olivine, pyroxenes and amphiboles (Fig.2A-D; Alene et al., 2000). The mafic and opaque minerals as mentioned above are quite susceptible to breakdown and capable of providing trace metals in significant quantities to groundwater.

Shear zones being good aquifers, have become sites for the construction of many hand dug wells. Since these zones show incidence of base metal mineralization with varying metal contents $(\mathrm{Cu}$, $\mathrm{Pb}$ and $\mathrm{Zn}$; and associated metals like Co, As, Cd, Ni, Cr etc) (Fig. 5) and whose concentrations are much higher than the normal background concentrations can cause serious long term health problems. So, it is essential to regularly monitor water quality and water related irrigation and other activities so as to avert possible human risks.

\section{CONCLUSION}

- The presence of chlorite, muscovite, biotite (rare) in metavolcanics, metavolcaniclastics and phyllite and development of foliation and crenulations in phyllite and moderately developed schistosity along the intrusive contacts and shear zones indicate that the rocks in the area have experienced low grade of metamorphism in the area. Minerals like tremolite and biotite are rare and localized.

- Among the three types of rocks (MV, MVC and MP), MVC consists of volcanic derived tuff dominated matrix and clasts of lithic fragments varying in composition, size, shape and mostly randomly oriented. 
- Opaques though are common in all rock types, those associated with hydrothermal veins are related to ore minerals.

- In the area the shear zones are commonly associated with green color malachite, sericite, quartz veins, moderately developed schistosity and elongated clasts. Copper anomalies together with malachite stains indicate a possible shear zone-controlled $\mathrm{Cu}$ mineralization where the source is related to basic metavolcanics. It is comparable with the nearby (Abrha Atsbha) shear zone-controlled Zn-mineralization where the source for $\mathrm{Zn}$ is related to metarhyolite.

- Groundwater geochemical data indicates that the water is safe for domestic purposes. Trace elements such as $\mathrm{Ni}$ and Fe are related to MV and MVC whereas $\mathrm{Pb}$ values to MP. The major elements Ca is related to plagioclase and epidote in MV and MVC, and Mg to chlorite in phyllite.

- Shear zones being mineralised and also form good targets for groundwater development, they need to be probed in detail to avoid long term human risks.

\section{ACKNOWLEDGEMENTS}

The study forms part of the NORAD-II funded project entitled "Qualitative and quantitative evaluation of metamorphites hosted base metal/ transition metal ( $\mathrm{Pb}, \mathrm{Zn}, \mathrm{Cu}, \mathrm{Fe}, \mathrm{Mn}, \mathrm{Ni}$, Ag and Co) mineralization and its impact on groundwater and its chemistry in the area around Negash, Hawzien and Wukro, Tigray Province, northern Ethiopia”. Authors duly acknowledge the funding provided by NORAD-II. Thanks are due to Drs. Mulugeta Alene, Addis Ababa University, Dirk Kuester, BGM and Kurkura Kebeto, Mekelle University for reviewing the manuscript and thanks are also due to Drs. Kuester and Nageshwar Dubey for going through the revised manuscript.

\section{REFERENCES}

Abdeselam, M.G \& Stern, R. J. 1996. Sutures and shear zones in the Arabian - Nubian shield. Journal of African Earth Science, 23: 289-310.

Alemu, T. 1998. Geochemistry of Neoproterozoic granitiods from the Axum area, northern Ethiopia. Journal of African Earth Science, 27:437-460. 
Alene, M., Ruffini, R \& Sacchi, R. 2000. Geochemistry and geotectonic setting of Neoproterozoic rocks from Northern Ethiopia (Arabian-Nubian shield). Gondwana Research, 3: 333-347.

Arkin, Y., Beyth, M., Dow, D.B., Levitte, D., Temesgen, H \& Tsegaye, H. 1971. Geological map of Mekelle sheet area ND 37- 11, Tigre Province. Geol. Surv. Ethiopia Publication, Ministry of Mines, Addis Ababa.

Asrat, A., Barbey, P \& Gleizes, G. 2001. The Precambrian geology of Ethiopia: a review. Africa Geoscince Review, 8 (3): 271-288.

Asrat, A. 2002. Structural (AMS), Petrological and Geochemical (Rb-Sr, Sm-Nd, U-Pb) studies of the Pan African Negash and Konso plutons (Ethiopia): Significance of mafic-felsic magma interactions to the construction of calc-alkaline plutons. Ph.D Thesis, Centre de Recherches Petrologiques \& Geochimiques, UPR 2300, 54501 Vandoeuvre-les-Nancy.

Ayalew, T., Bell, K., Moore, J.M \& Parih, R.R. 1990. U-Pb and Pb-Sr geochemistry of the western Ethiopian Shield. Geological Society of America Bulletin, 102: 1309-1316.

Bheemlingeswara, K \& Nata Tadesse, 2006. Assessment of groundwater quality in an area of low grade metamorphites and associated sporadic base metals sulfides around Negash, Hawzen and Wukro, Tigray Province, northern Ethiopia: A preliminary study. In: K. Bheemalingeswara and Mebrahtom Gebrekirstos (Eds.), Research Review 2006, Proceeding volume-I, Mekelle University, Mekelle, 35-47 pp.

David Shelly. 1993. Igneous and metamorphic rocks under microscope. Chapman \& Hall, 2-6 Boudary Row, London, 445p.

De Souza Filho, C.R \& Drury, S.A. 1998. A Neoproterozoic supra-subduction terrane in northern Eritrea, NE Africa. J. Geological Society of London, 155: 551-566.

Dwivedi, S. B. 2003. Metamorphites hosted base/ transition metal of the area around Negash, Tigrai Province, Northern Ethiopia. $4^{\text {th }}$ Ethiopian Geoscience and Mineral Engineering Association (EGMEA) Congress, Abstract Volume. Addis Ababa, 46-47 pp.

Edmunds, W.M \& Smedley, P.L. 1996. Groundwater geochemistry and health: an overview. In: J.D. Appleton, R. Fuge and G. J.H. McCall (Eds.), Environmental geochemistry and health. Geological Society of London, special. publication, 113: 91-105.

Fetter, C.W. 1994. Applied hydrogeology. Mac Millan College Publ. Company, Inc., New York. Garland, C.R.1980. Geology of Adigrat Area. Memoir,1. Min. Mines \& Energy, Ethiopia, 51 p. 
Genna, A., Nehlig, P., Le Goff, E., Guerrot, C \& Shanti, M. 2002. Proterozoic tectonism of the Arabian Shield. Precambrian Research, 117:21-40

Gerra, S. 2000. A short introduction to the geology of Ethiopia. Chron. Rech. Min., 540: 3-10.

Gichile, S. 1992. Granulites in the Precambrian basement of southern Ethiopia: geochemistry, PT conditiond of metamorphism and tectonic setting. J. Afr. Earth Sci., 15 (2): 251-263.

Gilboy, C.F. 1970. The Geology of the Gariboro region of southern Ethiopia. Ph.D thesis, University of Leeds, England.

Hem, J. D. 1992. Study and interpretation of the chemical characteristics of natural water. $3^{\text {rd }}$ Edition, Washington: United States Geological Survey, Water supply Paper, 2254p.

Jelene, D.A. 1996. Mineral occurrences of Ethiopia. Min. Mines \& Energy, Ethiopia, 450p.

Johnson, P.R \& Woldehaimanot, B. 2003. Development of the Arabian-Nubian Shield: perspectives on accretion and deformation in the northern East African Orogen and the assembly of Gondwana. In: M. Yoshida, B.E. Windley and S. Dasgupta (Eds.), Proterozoic East Gondwana: supercontinent assembly and breakup. Geol. Soc. London, special publication, 206: 289-325

Kazmin, V. 1973. The geological map of Ethiopia, 1:2,000,000. Geol. Surv., Addis, Ethiopia.

Kazmin, V., Shiferaw, A \& Balcha, T. 1978. The Ethiopian basement: stratigraphy and possible manner of evolution. Gologiche Rundschau, 67: 531-548.

Miller , J.A., Mohr, P.A \& Rogers, A.S. 1967. Some new K-Ar age determinations of basement rocks from Eritrea. Bulletin of Geophysical Observatory, AAU, Ethiopia, 10 :53-57.

Miller, N.R., Alene, M., Sacchi, R., Stern, R.J., Conti, A., Kroner, A \& Zuppi. G. 2003. Significance of the Tambian Group (Tigrai, N. Ethiopia) for snowball earth events in the Arabian - Nubian Shield. Precambrian Research, 121: 263-283.

Mock, C., Arnaud, N.O., Cantagrel, J.M \& Yirgu, G. 1999. ${ }^{40} \mathrm{Ar} /{ }^{39} \mathrm{Ar}$ Thermochronology of the Ethiopian and Yemeni basements: reheating related to the Afar plume ? Tectonophysics, 314 :351-372.

Pearce, J.A, 1980. Geochemical evidence for the genesis and eruptive setting of lavas from Tethyan ophiolites. In: A. Panayiotou (Ed.), Ophioplites. Proceedings of International ophiolite symposium. Geological Survey Department, Nicosia, Cyprus, 261-277.

Rogers, A.S., Miller, J. A \& Mohr, P.A. 1965. Age determinations on some Ethiopian basement rocks. Nature, 206:1021-1023. 
Shackleton, R.M.1994. Review of the Late Proterozoic sutures, ophiolitic melanges and tectonics of Eastern Egypt and Northern Sudan. Geol. Runsdchau, 83:537-546.

Shackleton, R.M.1996. The final collision zone between East and West Gondwana. Journal of African Earth Science, 23: 271-287.

Stern, R.J. 1994. Neoproterozoic (900-550 Ma) arc assembly and continental collision in the East African Orogen: implications for consolidation of Gondwanaland. Ann. Rev. Earth Planet Sci., 22:319-351

Stoeser, D.B \& Camp, V.E. 1985. Pan- African microplate accretion of the Arabian Shield. Geol. Soc. Am. Bull., 96: 817-826.

Tadesse, T. 1996. Structure across a possible intra-oceanic suture zone in the low grade PanAfrican rocks of northern Ethiopia. Journal of African Earth Science, 23: 375-381.

Tadesse, T., Hoshino, M., Suzuki, K \& Iizumi, S. 2000. Sm-Nd, Rb-Sr and Th-U-Pb zircon ages of syn-and post- tectonic granitoids from the Axum area of northern Ethiopia. Journal of African Earth Science, 30: 313-327.

Tadesse, G \& Allen, A. 2002.Geology and geochemistry of the Neoproterozoic Tuludimtu Orogenic belt, western Ethiopia. In: $19^{\text {th }}$ Colloquium of African Geology- El Jadida, Morocco, Abstract volume, 173-174.

Tadesse T, Hoshino, M \& Sawada, Y. 1999. Geochemistry of low grade metamorphic rocks from the Pan-African of the Axum area, northern Erthiopia. Precam. Res., 99: 101-124.

Teklay, M., Kröner, A., Mezger, K \& Oberhänsli, R. 1998. Geochemistry, Pb-Pb single zircon ages and $\mathrm{Nd}-\mathrm{Sr}$ isotope composition of Precambrian rocks from southern and eastern Ethiopia: implications for crustal evolution in East Africa. J. Afr. Earth Sci., 26:207-227

Todd, D.K.1980. Groundwater Hydrology. John Willy and Sons, Inc., New York.

Vail, J.R. 1983. Pan-Africal crustal accretion in north-east Africa. J. Afr, Earth Sci., 1: 285-294.

Vail, J.R. 1988. Tectonics and evolution of the Proterozoic basement of north-east Africa. In: S. El-Gaby and R.O. Grieling (Eds.), The Pan African Belt of Northeast Africa and adjacent areas. Friedr. Vieweg and Sohn, Braunschweig/Wiesbaden, 195-226.

WHO. 1993. Guidelines for drinking water quality Geneva.

Worku, H \& Schandelmeier, H. 1996. Tectonic evolution of the Neoproterozoic Adola Belt of southern Ethiopia: evidence for a Wilson Cycle process and implications for oblique plate collision. Precambrian Research, 77:179-210. 